\title{
SELAYANG PANDANG HARMONISASI SPIRITUAL SUFI DALAM PSIKOLOGI AGAMA
}

\author{
Saliyo \\ Jurusan Bimbingan dan Konseling Islam \\ Sekolah Tinggi Agama Islam Negeri (STAIN) Kudus
}

\begin{abstract}
Abstrak - Agama berkaitan dengan perilaku manusia yang bersifat formal dilakukan secara bersama dan doktrin yang bersifat umum. Sisi lain spiritual berkaitan dengan perilaku yang unik, personal dan non formal. Terkadang sulit membedakan antara agama dan spiritual. Terkadang spiritual menjadi agama dalam agama. Bentuk spiritual dalam agama Islam adalah perilaku sufi. Sufi bagi penganutnya menjadi agama dalam agama. Sufi mengajarkan penganutnya untuk bisa bertemu dengan Tuhan. Itulah pesona yang selalu ditebarkan oleh orang-orang sufi. Diantara ajaran sufi yang dapat bertemu dengan Tuhan adalah ajaran sufi Jalaludin Rumi. Jalan cinta sufi Jalaludin Rumi, sufi tidak hanya melampaui dunia sekarang yang dialaminya. Cinta sufi menembus dunia masa depan yang hanya dijangkau melalui imajinasi sekarang. Menurut Rumi cinta tidak dapat diungkapkan lewat kata-kata saja. Cinta adalah pengalaman yang berada dalam seberang pemikiran. Cinta adalah pengalaman yang lebih nyata daripada dunia dan segala yang ada di dalamnya. Ilmu psikologi menjelaskan bahwa cinta memiliki tiga komponen yaitu pengasuhan, kasih sayang, dan keakraban. Pengasuhan memiliki makna bimbingan dan tuntunan menuju jalan yang benar. Kasih sayang merupakan kebutuhan ingin bersama untuk mengadakan kontak fisik dan untuk memilikinya. Keakraban merupakan ikatan khusus saling pengertian tak terucapkan dari keduanya. Keakraban merupakan hal yang eksklusif yang melibatkan komunikasi yang hanya dimengerti oleh orang yang saling mencintai. Kesimpulannya agama sufi mengajarkan untuk cinta terhadap Tuhan. Seseorang yang mampu menembus derajat cinta terhadap Tuhan akan melahirkan kehidupan yang damai, tenang dengan penuh keharmonisan. Cinta melahirkan kebahagiaan, kebermaknaan dan kepuasan. Cinta melarang pertikaian, dan penistaan.
\end{abstract}

Kata Kunci: Harmonisasi, Agama Sufi, dan Psikologi Agama

PSIKOISLAMIKA. Jurnal Psikologi Islam (JPI) copyright @ 2014 Laboratorium Penelitian, Kajian Psikologi Islam dan Penerbitan. Volume 11. Nomor 2, Tahun 2014

\section{PENDAHULUAN}

Pada zaman kuno penyakit yang diderita manusia sering diasumsikan dengan masalah-masalah spiritual. Orang-orang terdahulu mengasumsikan bahwa seseorang yang sedang sakit dikarenakan kerasukan setan atau makhluk halus. Pengobatan untuk orang-orang sakit di zaman dahulu dilakukan dengan cara mencari dukun ahli spiritual yang mampu berkomunikasi dan menghilangkannya. Sebaliknya di era modern orang yang sakit didiagnosa berdasarkan gajala-gajala biologis. Pola pikir bahwa orang sakit karena dirasuki roh jahat semakin terkikis. Roh jahat berbentuk wujud dalam pikiran orang modern menjadi kuman-kuman yang merusak tubuh manusia. Kuman-kuman tersebut dapat dideteksi dengan alat kedokteran yang canggih yaitu mikroskop (Jalaludin, 2010).

Carl Gustav Jung berpendapat bahwa diantara pasien yang sudah tua tidak ada yang menderita penyakit jiwa karena ada hubungannya dengan agama. Agama sangat berkaitan dengan ilmu kedokteran dalam mengobati orang sakit. Apabila keduanya berjalan dengan baik, maka tingkat kesembuhan akan lebih cepat. Dilain sisi, bahwa agama selain memiliki peran dalam dunia medis, juga berperan dalam perubahan sosial. Peran yang penting dalam 
perubahan sosial agama adalah pada sisi penyesuaian sosial, struktur sosial (Jalaludin, 2010).

Pandangan lain mengenai agama dikemukakan oleh Freud. Agama dapat menjadikan kesalehan bagi manusia. Kesalehan tersebut ada dua jenis yaitu kesalehan yang feminim dan kesalehan maskulin. Kesalehan maskulin karena Freud terbentuk dari kebiasaan orang tuanya diajak ke gereja. Lain sisi kesalehan feminin terbentuk secara emosional oleh kesalehan umat Katolik. Perjalanan tersebut menjadi jelas bahwa analisis Freud tentang agama lebih menonjol sisi maskulinnya (Scharfenberg, 1968).

Menurut Freud bahwa seseorang yang melakukan praktik agama ataupun ritual agama bukan masuk dalam katagori neurosis. Alasannya bahwa aktivitasaktivitas religius dilakukan dengan sengaja dan sadar. Orang tersebut melakukan hal tersebut karena ingin memiliki makna yang bersifat simbolis. Maka Freud memberikan nama bahwa neurosis kompulsif sebagai penyimpangan agama privat yang separoh tragis dan separoh komedi. Sepanjang manusia sadar dengan makna dan simbol dari ritual agama yang dilakukan oleh seseorang, maka orang tersebut tidak berada dalam ranah penderita neurosis (Scharfenberg, 1968).

Perilaku manusia dapat dikaji dalam sisi estetika, etika dan religius. Perilaku seseorang yang pertama adalah berpijak pada estetika. Perilaku ini berdasarkan pada naluri-naluri sensual, mood, dan hati. Dalam benaknya bagi seseorang yang berperilaku berpijak pada estetika adalah pencapaian kepuasan fisik dan batin. Ciri utama orang berperilaku estetika adalah ketiadaan komitmen dalam berperilaku. Terkadang dia tampil seperti seniman, filsuf, agamawan, intelektual dan lain-lain. Nilai-nilai estetika sebagai topeng wajahnya dari nilai-nilai yang ada dalam hatinya. Akhir dari kehidupan yang demikian berujung pada keputusasaan yang mendalam. Hal demikian terjadi karena orang tersebut hidup tanpa standar moral yang mengikat, dan tanpa kerangka makna (Sugiharto \& Rachmat, 2000).

Perilaku kedua adalah perilaku yang berpijak pada keutamaan-keutamaan etik atau moral. Cita-cita dari orang yang berpijak pada perilaku moral kepribadiannya mengubah dan mengarahkan dirinya sesuai dengan moral. Hidup bagi orang yang berpijak pada etik bukan kepuasan diri sendiri, tetapi kepuasan bersifat kemanusiaan dan universal. Ungkapan-ungkapan pribadinya bukan lagi bersifat verbal, tetapi bersifat kongkrit, mendalam dan bermakna. Sebagai contoh adalah pernikahan. Pernikahan adalah hidup bukan untuk diri sendiri, tetapi untuk banyak orang dan menjalankan komitmen (Sugiharto \& Rachmat, 2000).

Meningkat dari perilaku berdasarkan etika menjadi jiwa yang religius. Jiwa religius adalah jiwa yang berdasarkan iman. Iman selalu membentengi seseorang untuk tidak berbuat dosa. Iman adalah rahmat dari Tuhan dan panggilan hati. Hidup religius memang terkadang ditandai dengan kehidupan yang paradok. Tuhan itu jauh baginya sekaligus dekat. Untuk menemukan Tuhan dalam hatinya terkadang dengan kehilangan diri bahkan penderitaan dalam kebahagiaan. Hidup religius yang asli adalah hidup yang tersenyum dalam duka, damai dalam aneka ketegangan, melangkah ringan pada saat menyesakkan. Orang yang beriman sejati menjadi pendekar keimanan. Dia sangat menghargai dalam hal yang sederhana ataupun kecil bentuknya (Sugiharto \& Rachmat, 2000).

Religius atau dalam bahasa yang dikenal orang adalah agama. Apa sebenarnya agama. Seseorang yang beragama mau bepetualang dengan penderitaan dalam kebahagiaan. Agama adalah seperangkat keyakinan adanya Tuhan. Agama adalah satu kepercayaan keyakinan tentang arah dan pedoman dalam hidup atau kepedulian tertinggi (ultimate concern). Sisi lain orang mendefinisikan sebagai cita rasa akan adanya misteri. Definisi tersebut banyak yang tidak menyangkalnya. Bahkan Albert Einstein seorang ateis yang menyangkal eksistensi Tuhan, menerima bahwa alam semesta memang penuh dengan misteri. Misteri tersebut berkaitan dengan sesuatu yang Maha Kuasa yaitu Tuhan (Haught, 1995).

Segala yang ada di dunia ini tidak abadi. Ada hukum di dunia yang disepakati banyak orang yaitu tidak ada keabadian. Segalanya akan berubah memudar dan setelah itu mati. Ada batasan waktu dan ruang. Sekarang pertanyaanya bagaimana dengan agama.

Apakah ada terbatasnya ruang dan waktu bagi hidupnya agama?. Kalau ada orang yang memiliki kekuatan kekuasaan menghabisi pemeluk agama akankah agama mati bersamanya. Jawabannya tidak. Agama tidak akan mati. Mungkin boleh saja pemeluk-pemeluk agama mati, tetapi agama tidak akan mati sepanjang zaman. Agama tetap akan hidup tidak terpadamkan. Detak jantung agama akan terus berdenyut selama dunia dan manusia ada. Agama akan tetap hadir dalam rupa yang berbeda (Muthahhari, 1995). 
Pendapat di atas diperkuat oleh Will Durant, seorang penulis yang tidak percaya pada agama manapun. Dia mengatakan bahwa agama memiliki seratus jiwa. Segala sesuatu apabila telah terbunuh, pada saat ajal telah menusuk dirinya, maka selamanya akan mati. Berbeda dengan agama sekali terbunuh tetap akan hadir lagi. Bahkan seribu kali terbunuh agama akan lahir dalam wujud rupa yang berbeda (Muthahhari, 1995).

Pertanyaan selanjutnya mengapa agama mengalami keabadian?. Jawabannya karena agama terlahir sebagai konsumsi kebutuhan manusia. Kebutuhan manusia ada dua. Kebutuhan alamiah dan kebutuhan non alamiah. Kebutuhan alamiah manusia bersifat fitrah. Kebutuhan tersebut berkaitan dengan hal-hal yang dibutuhkan manusia sebagai manusia. Sampai saat ini kebutuhan tersebut belum dapat diketahui rahasianya. Sebagai contoh mengapa manusia ingin cantik, tampan, atau memiliki keturunan?. Walaupun susah mendapatkannya bahkan mahal ongkos pemeliharaannya, orang akan tetap berusaha mencapainya. Hal demikian walaupun manusia dapat menggapai atau tidak, hal tersebut merupakan naluri manusia (Muthahhari, 1995).

Kebutuhan yang non alamiah adalah kebutuhan yang bersifat kebiasaan. Sebagai contoh merokok, minum kopi, maka kebutuhan tersebut dapat diganti dengan yang lain, walaupun terkadang kebiasaankebiasaan tersebut menjadi kebutuhan yang sulit ditinggalkan. Kebutuhan tersebut dapat diganti dengan kebutuhan yang lain (Muthahhari, 1995).

Kajian psikologi tentang perilaku manusia seperti yang dilakukan Pavlov dan Skiner bahwa perilaku manusia karena berdasarkan insting. Mereka melakukan penelitian yang sederhana bahwa perilaku binatang karena ada proses belajar. Hasilnya disamakan dengan perilaku manusia. Mereka lupa bahwa manusia memiliki sesuatu yang berkaitan dengan kesadaran dan pengalaman. Manusia memiliki rasa dan dapat berpikir. Aktivitas manusia terkadang bersifat objektif dan subjektif. Hal yang demikian aliran behavioris melupakan tentang revolusi kognitif. Sisi lain manusia berkaitan dengan kesadaran memiliki rencana, peran, nilai, teori, penjelasan, dan pengalaman. Binatang hanya memiliki aktivitas kognitif seperti mental maps. Manusia memiliki bahasa yang dapat digunakan untuk komunikasi, memberikan katagori-katagori peristiwa dan pengalaman (Argyle, 2000).

Revolusi ilmu pengetahuan sejak abad 16, Francis Bacon berpendapat bahwa tidak ada konflik antara ilmu pengetahuan dan agama. Dia juga berpendapat bahwa ilmu pengetahuan bukanlah budak dari agama. Pada abad 17, Newton dan Boyle mengajarkan dalam temuan-temuannya seperti teori gravitasi. Menurutnya bahwa gravitasi merupakan desain Tuhan yang bersifat universal. Hukum gravitasi bukan alamiah semata, tetapi karena ada campur tangan Tuhan untuk mendesain apa yang ada di bumi. Newton juga mengajarkan bahwa Tuhan selalu ada dan sifatnya natural yang ada dalam dunia. Itulah pendapat ilmuwan yang tidak berseberangan dengan agama (Argyle, 2000).

Ilmu sosiologi tertarik hubungan antara agama dengan fungsi personal dalam sejarah manusia yang sangat panjang. Durkheim menggambarkan bahwa manfaat agama adalah proses afektif dan keterpaduan dalam kelompok. Davis menyatakan agama adalah cerita yang bermanfaat sebab manyarakat atau manusia memiliki kecenderungan untuk membantu dalam kehidupan sehari-hari. Marx menggambarkan bahwa agama adalah bentuk manfaat dari pengalaman pribadi dan organisasi kemasyarakatan (Schieman, 2003). James (1902) mendefinisikan agama sebagai perasaan, aksi dan pengalaman individu dalam kesunyian untuk memahami pendirian mereka dalam kaitanya dengan apa saja yang berhubungan dengan Tuhan (James, 1902).

Perkembangan literatur agama berkembang pesat. Agama sering dikaitkan dengan kesehatan fisik dan mental yang lebih baik. Selangkah lebih meningkat agama dikaitkan sengan perasaan kebahagiaan. Dampak dari keagamaan yang lebih luas adalah adanya penemuan tentang kepuasan hidup, kebahagiaan, konsep diri, dan rasa optimis. Pada penelitian lain agama juga dikaitkan dengan religious coping, ibadah dan dukungan sosial. Semua peran-peran aktivitas agama memiliki peran dalam proses kehidupan manusia. Hal yang lebih penting lagi adalah agama berkaitan dengan makna (Krause, 2003).

Agama yang bermakna sering didefinisikan sebagai sebuah proses kecenderungan agama yang selalu berusaha untuk menemukan tujuan hidup secara langsung dalam kehidupan dan memiliki argumentasi dalam eksistensi diri. Frankl berpendapat bahwa keinginan untuk menemukan makna adalah kekuatan motivasi dalam kehidupan. Maka dasar dari kehidupan beragama sebenarnya adalah untuk memenuhi kebutuhan dasar manusia. Clark berpendapat bahwa agama berfungsi menemukan kepuasan dan makna hidup seorang (Krause, 2003). Pendapat lain menurut Pargement (1997) esensi 
dari agama adalah berusaha menemukan makna hidup.

Ulasan di atas dapat disimpulkan bahwa agama memberikan dampak positif dalam psikis manusia. Agama mampu memberikan makna kebahagiaan dan kepuasaan bagi penganutnya. Agama bermanfaat bagi manusia.

\section{DISKUSI}

Membahas agama tidak lepas dari spiritual. Dua hal tersebut terkadang banyak orang yang menyamakannya. Di sisi lain ada juga yang membedakannya. Mengapa ada orang yang menyamakannya. Masalahnya esensi dari keduannya sama yaitu melaksanakan ajaran-ajaran Tuhan. Berbeda lagi bagi orang yang memberikan perbedaan dua hal tersebut. Permasalahannya adalah keduannya memiliki tingkat praktik hubungan manusia dengan Tuhannya sangat berbeda.

Spiritual memiliki makna yang bersinggungan dengan jiwa. Lebih jelas lagi spiritual memiliki makna berkaitan dengan dasar jiwa seseorang (Oxford English Dictionary, 2002). Jiwa merupakan representasi prinsip-prinsip hidup manusia. Jiwa mengajarkan tindakan khususnya fokus pada aspek moral, emosi, dan mental manusia yang bersifat alami. Soul atau jiwa dalam kajian filsafat memiliki aspek yang sangat penting, sensitif, rasional dalam prinsip-prinsip kehidupan manusia (Oxford English Dictionary, 2002). Lebih jelas lagi soul berkaitan dengan visi pada dua hal yaitu bekerja dan hidup. Soul memiliki energi yang kuat untuk mengorganisirnya dalam rangka mencapai tujuan hidup (Csikszentmihalyi, 2003). Definisi lain berkaitan dengan spiritual bahwa spiritual berkaitan dengan intelektual, pengetahuan, pemahaman, dan berpikir abstrak (American Heritage Dictionary, 2000).

Mempertajam lagi pengertian spiritual berkaitan dengan ajaran ataupun keyakinan yang mendalam. Spiritual juga sering dipahami sebagai hubungan transendental. Hubungan tersebut berkaitan dengan eksistensi diri yang bersifat fisik ataupun psikologis. Spiritual berkaitan dengan hal-hal yang sifatnya esoteris, energi yang tinggi, dan realitas transendental. Konsep spiritual berkaitan dengan hal-hal yang sifatnya esoteris, magis, dan mistik (Kari, 2006).

Bagaimana dengan agama?. Apa perbedaan agama dengan spiritual. Spiritual memiliki tipikal yang bersifat informal, personal. Agama memiliki tipikal sebaliknya yaitu formal. Negara memiliki kekuasaan secara sosial dan politik untuk menginterpretasikan spiritual. Agama berkaitan dengan doktrin yang bersifat umum, simpel dan praktik-praktik ritual yang bersifat tradisi. Peribadatan dalam agama bercampur atau bersama dengan yang lain (Kari, 2006).

Mengapa orang beragama?. Penjelasan mengapa orang beragama banyak ilmuan menjelaskan masalah tersebut. Diantara penjelasan mengapa orang beragama adalah; pertama bahwa agama merupakan produk dari rasa takut. Rasa takut dapat muncul dari berbagai hal. Misalnya dari alam seperti petir, gunung meletus dan lain sebagainya (Muthahhari, 1995). Pada konteks ini, agama mampu menjawab kebutuhan manusia. Agama mampu memberikan ketenangan pada manusia. Sebagaimana teori hierarki kebutuhan Abraham Maslow bahwa manusia memiliki rasa nyaman, bebas dari rasa takut.

Kedua mengapa orang beragama. Agama merupakan produk dari kebodohan. Mengapa orang beragama karena ketidaktahuan seseorang pada gejala-gejala alam. Orang tidak mendapatkan penjelasan yang rasional ilmiah. Selanjutnya orang tersebut mengembalikan pada hal yang berkuasa yaitu Tuhan. Ketiga seseorang beragama karena mengharapkan keadilan dan keteraturan. Ketika masyarakat mendapatkan ketidakadilan, kezaliman dalam masyarakat, orang menciptakan ataupun menganut agama. Menjalankan aturan-aturan ajaran agama mewujudkan keteraturan kehidupan sosial. Hal tersebut menjawab harapan keadilan dan keteraturan masyarakat (Muthahhari, 1995).

Selain agama yang dapat menjawab kebutuhan manusia di atas adalah spiritual. Spiritual pada sisi tertentu ada persamaan dan perbedaan dengan agama. Persamaannya adalah sama-sama menghadap pada Tuhan. Agama Islam mengenal spiritual diantaranya adalah perilaku sufi.

Sufi muncul dari paham dan kesalehan kegiatan para pengkhotbah. Gerakan tersebut berkembang pesat sejak abad ke $5 \mathrm{H} / 11 \mathrm{M}$. Sufi berkembang terus secara cepat dan mencengangkan menjadi ordo-ordo sufi seluruh penjuru dunia Islam. Pada abad ke 3 H/9 M sufisme mulai diajarkan secara terbuka di Baghdad. Sufisme menjadi magnet yang sangat luar biasa bagi masyarakat awam. Dakwah sufisme yang menjadi magnet pada masyarakat awam diantaranya; Pertama sufisme mendakwahkan dapat membawa pengikut-pengikutnya untuk bertemu dengan Tuhan. Pesona keagamaan yang ditebarkan sufi sangat kuat. Lama kelamaan sufi menjelma menjadi agama dalam agama (Rahman, 1997). 
Diantara ajaran sufi untuk membawa pengikutnya bertemu dengan Tuhan adalah ajaran cinta. Cinta menjadi tema sentral ajaran sufi dari Rumi. Jalaludin Rumi menjelaskan bahwa cinta sebagai dimensi pengalaman rohani. Cinta itu tidak cukup dapat dijelaskan dengan kata-kata, cinta dapat dipahami dengan pengalaman. Sebagaimana sepasang kekasih laki-laki pada perempuan atau perempuan pada laki-laki, bahwa cintanya tidak cukup dituliskan dalam kertas. Sama halnya cinta sufi pada kekasinnya yaitu Tuhan. Cinta sufi tidak hanya melampaui dunia sekarang yang dialaminya. Cinta sufi menembus dunia masa depan yang hanya dijangkau melalui imajinasi sekarang. Menurut Rumi cinta tidak dapat terungkapkan lewat kata-kata saja. Cinta adalah pengalaman yang berada dalam seberang pemikiran. Cinta adalah pengalaman yang lebih nyata daripada dunia dan segala yang ada di dalamnya (Chittick, 2003).

Cinta memang sulit diungkapkan. Cinta lebih mudah dirasakan dan dimajinasikan. Zick Rubin meneliti apa makna cinta. Dia memberikan daftar pertanyaan kepada mahasiswa yang dapat mewakili mereka pada apa yang mereka sukai. Hasil penelitiannya menyimpulkan bahwa cinta berbeda dengan sesuatu yang disukai. Cinta memiliki tiga komponen yaitu pengasuhan, kasih sayang, dan keakraban (Calhoun \& Acocella, 1995).

Kasih sayang merupakan kebutuhan ingin bersama orang lain untuk mengadakan kontak fisik dan untuk memilikinya. Hal yang demikian orang Yunani Kuno menyebutnya dengan eros. Erich Fromm dalam bukunya The Art of Loving menamakan perhatian aktif terhadap kehidupan dan pertumbuhan sesuatu yang kita cintai. Keakraban menurut Rubin merupakan ikatan khusus antara dua orang dan sangat jelas nampak saling pengertian tidak terucapkan dari keduanya. Keakraban merupakan hal yang eksklusif yang melibatkan komunikasi yang hanya dimengerti oleh dua orang yang saling mencintai (Calhoun \& Acocella, 1995).

Bagaimana dengan kesukaan. Apa bedanya dengan cinta?. Rubin berpendapat bahwa kesukaan merupakan sesuatu yang kurang berhubungan dengan rasa cinta. Mengapa?. Biasanya seseorang mulai menyenangi seseorang, selanjutnya tumbuh benih cinta. Kesukaan tidak muncul gairah yang mendalam, harapan untuk memberi, dan ikatan yang eksklusif. Menurut Rubin sikap yang paling menentukan ketika menyukai seseorang adalah penilaian positif, rasa menghormati, rasa kepercayaan, dan rasa kesamaan (Calhoun \& Acocella, 1995).
Ellen membedakan antara mencintai dan menyukai. Menurutnya persahabatan tidak memiliki elemen khayalan yang biasanya ada dalam cinta. Persahabatan tidak melibatkan emosi yang bertentangan seperti benci yang sering menyertai nafsu cinta. Cinta semacam ikatan permusuhan yang sangat penting untuk memelihara dunia berkembang. Persahabatan lebih mantap daripada cinta yang penuh dengan nafsu. Cinta penuh nafsu akan hilang dengan diterpa waktu. Apa yang terjadi ketika cinta penuh nafsu menjadi padam. Apabila hubungan berlanjut akan digantikan dengan cinta yang berbeda yaitu bersahabat. Emosi tidak pasang surut nafsu cinta yang menakutkan. Emosi berbentuk rasa kasih sayang dan menyenangkan terhadap seseorang yang hidupnya sangat dekat dan telah berbagi pengalaman dalam waktu yang cukup lama. Cinta yang bersahabat merupakan dasar perkawinan yang membahagiakan (Calhoun \& Acocella, 1995).

Apa kaitannya ajaran cinta orang-orang sufi dengan cinta yang ada pada manusia. Apabila dipahami secara mendalam tentang penjelasan cinta di atas, tidak ditemukan setitik air yang keruh menodai, menyakiti, mengancam, dan melukai satu sama lain. Kalau ada emosi, emosi tersebut tumbuh karena kasih sayang dan kekaraban. Emosi itu tumbuh karena rasa memiliki dan pengasuhan bukan penistaan atau penghancuran. Cinta menghasilkan kedamaian dan ketenangan. Cinta melahirkan pengasuhan saling menghargai dan saling menyayangi. Cinta melahirkan kehidupan saling melengkapi kekurangan dan kelebihan yang menjalinnya.

Mengapa agama sufi melahirkan kehidupan yang harmonis. Sebab sufi memiliki ajaran cinta. Cinta untuk bertemu dengan Tuhan. Bagaimana benih-benih cinta dapat tumbuh bersemi bagi pengembara sufi. Masalahnya ada jalan. Jalan tersebut dinamakan maqom. Maqom tersebut berupa taubat, wara', zuhud, sabar, fakir, tawakal, ridha, mahabah dan ma'rifat. Semua terbagi menjadi tiga sifat yaitu takhali, tahali dan tajali (Siraj, 2012).

Takhali tahapan pertama adalah membersihkan hati keterikatan dengan dunia. Tahapan pertama ini diisi dengan jalan cinta terhadap Tuhan yaitu taubat, wara', dan zuhud. Taubat adalah langkah awal memasuki sufi. Taubat tidak hanya diucapkan dalam lisan, tetapi dalam hati yang terwujud dalam perilaku komitmen untuk tidak melakukan perbuatan dosa, kemaksiatan dan lain sebagainya. Taubat dilakukan dengan keikhlasan tidak melakukan dosa, tetapi akan melakukan perbuatan baik. Setelah 
taubat wara'. Wara' adalah sikap kehati-hatian dalam melangkah, dan berbuat. Perbuatan seorang sufi selalu berhati-hati yang tidak mengandung dosa. Sikap tersebut terwujud dalam ucapan, bergaul, makan dan minum. Selanjutnya zuhud. Zuhud bukan berarti harus miskin. Zuhud memandang dunia dengan nilai rendah dan tidak terikat hatinya dengannya. Dunia bukan tujuan semata-mata. Dunia hanya menjadi alat saja. Maka orang sufi ketika ditinggalkan masalah dunia tidak bersedih kecewa (Siroj, 2012).

Tahapan selanjutnya adalah tahali. Tahapan ini adalah pengisian hati yang telah dikosongkan. Tahapan ini tumbuh benih-benih cinta terhadap Tuhan. Cinta tumbuh karena ada pengasuhan, keakraban dan kasih sayang. Ajaran tasawuf mengisi dengan sabar, fakir, tawakal dan ridha. Sabar menjalankan dan menerima dengan hati ikhlas. Seorang sufi tidak pernah terbesit katapun untuk menuntut pemberian Tuhan. Seorang sufi selalu menerima apa adanya. Fakir adalah sikap perasaan hati seseorang yang meyakini bahwa tidak ada satupun dalam hidup ini yang dimilikinya. Semua milik Allah dan akan kembali kepadanya. Tawakal adalah sikap perasaan semua milik Allah. Ridha adalah sikap dan perasaan menerima ketetapan dan ketentuan Tuhan (Siroj, 2012).

\section{DAFTAR PUSTAKA}

American Heritage Dictionary. 2000. American Heritage Dictionary of the English Language, 4th ed. Boston: Houghton-Mifflin.

Argyle, M. 2000. Psychology And Religion, An Introduction. London: Routledge.

Calhoun, J.F., \& Acocella, J.R. 1990. Paychology of Adjustment and Human Relathionship, Diterjemahkan Satmoko (1995). Psikologi tentang Penyesuaian dan Hubungan Kemanusiaan. Semarang: IKIP Press.

Chittick, W.C. 2003. Jalan Cinta Sang Sufi. Yogyakarta: Qalam.

Csikszentmihalyi, M. 2003. Good Business: Leadership, Flow and the Making of Meaning. New York: Viking Press.

Haught, J.F. 1995. Science and Religion: From Conflict to Conversation, Diterjemahkan Fransiskus Borgias, (2004). Perjumpaan Sains dan Agama: Dari Konflik ke Dialog. Bandung: Mizan.
Tahapan selanjutnya adalah tajali. Tahapan ini mendapatkan kebahagiaan sejati. Seorang sufi merasa selalu bersama Allah dalam kenikmatan yang tidak terlukiskan. la bahagia dalam keridhoannya. Tahap ini sufi memasuki tahap ma'rifat. Ma'rifat adalah mengetahui dan bersama Allah dimana saja dan kapan saja. Tahap ini juga seorang sufi mencapai tahapan mahabah atau cinta (Siroj, 2012).

Tingkatan tinggi derajat manusia seorang sufi yaitu cinta kepada Allah. Cinta tidak menuntut pada kekasihnya untuk memberi. Cinta juga tidak menuntut apa-apa kepada kekasihnya. Cinta akan selalu menghargai pemberiannya dalam bentuk sekecil apapun. Cinta akan selalu bersama dengan kekasihnya, walaupun dalam wujud yang abstrak. Cinta melahirkan perdamaian, keharmonisan, ketenangan dan kerukunan. Cinta melahirkan kasih sayang bersama. Diantara jalan cinta adalah dengan menganut jalan agama sufi.

\section{KESIMPULAN}

Agama sufi mengajarkan untuk cinta terhadap Tuhan. Seseorang yang mampu menembus derajat cinta terhadap Tuhan akan melahirkan kehidupan yang damai, tenang dengan penuh keharmonisan. Cinta melahirkan kebahagiaan, kebermaknaan dan kepuasan. Cinta melarang pertikaian, dan penistaan.

Jalaludin. 2010. Psikologi Agama. Jakarta: RajaGrafindo Persada.

James, W. 1902. The Varieties of Religious Experience. Diterjemahkan Lutfi Anshari (2003), Pengalaman Pengalaman Religius Sebuah Karya Klasik Yang Monumental Tentang Agama. Yogyakarta: Jendela.

Kari, J. 2006. A Review of the Spiritual In Information Studies. Journal of Documentation, Vol. 63, No. 6, 935-962.

Krause, N. 2003. Religious Meaning and Subjective Well Being, The Journal of Gerontology, Vol. 58 B. No. 3, 160-170.

Muthahhari, M. 1995. Perspektif al-Qur'an Tentang Manusia dan Agama. Bandung: Mizan.

Oxford English Dictionary. 2002. Oxford English Dictionary, 5th ed., Vols 1 and 2, Oxford.

Pargament, K.I. 1997. The Psychology of Religion and Coping: Theory Research and Practice. New York: Guilford Press. 
Rahman, F. 1997. Islam. Bandung: Pustaka.

Scharfenberg, J. 1968. Sigmund Freud und seine Regionskritik als Herausforderung fur den christlichen Glauben, Diterjemahkan Shohifullah, Subhan Zaenuri, Zulkifli, (2003). Sigmund Freud Pemikiran dan Kritik Agama, Yogyakarta: Ak Group.
Schieman, S., Nguyen, K., \& Elliott, D. 2003. Religiosity Socioeconomic Status, and the Sense of Mastery, Social Psychology Quarterly, Vol. 66, No. 3, 202-221.

Siraj, S.A. 2012. Dialog Tasawuf Kiai Said Akidah Tasawuf dan Relasi Antar Umat Beragama. Jakarta: LTN PBNU.

Sugiharto, I.B., \& Rachmat, W.A. 2000. Wajah Baru Etika \& Agama. Yogyakarta: Kanisius. 